\title{
HUBUNGAN ANTARA INDEKS MASSA TUBUH (IMT) IBU PRAHAMIL DAN KENAIKAN BERAT BADAN SELAMA KEHAMILAN DENGAN BERAT BADAN LAHIR BAYI DI RSUD DR. M. SOEWANDHIE SURABAYA
}

\author{
Irma Maya Puspita \\ Kebidanan, Universitas Muhammadiyah Surabaya, irmamayapuspita@gmail.com
}

\section{INFO ARTIKEL}

Riwayat Artikel:

Diterima: 04-06-2019

Disetujui: 20-07-2019

\author{
Kata Kunci: \\ Indeks Massa Tubuh, \\ Kenaikan Berat Badan \\ Selama Kehamilan, \\ Berat Badan Lahir Bayi
}

\begin{abstract}
ABSTRAK
Abstrak: Status gizi ibu sebelum dan selama kehamilan merupakan salah satu faktor yang mempengaruhi berat badan lahir bayi. Berat badan ibu sebelum hamil dan kenaikan berat badan selama kehamilan kurang (underweight) atau lebih (overweight) dari normal akan membuat kehamilan menjadi berisiko. Tujuan dari penelitian ini adalah untuk mempelajari hubungan antara indeks massa tubuh ibu prahamil dan kenaikan berat badan selama kehamilan dengan berat badan lahir bayi di RSUD Dr. M. Soewandhie Surabaya. Penelitian ini menggunakan rancangan penelitian analitik observasional dengan pendekatan cross sectional. Sampel dari penelitian ini adalah seluruh ibu postpartum di ruang nifas RSUD Dr. M. Soewandhie Surabaya. Besar sampel sebanyak 79 ibu postpartum. Analisa data yang digunakan adalah koefisian korelasi Spearman (rs). Hasil penelitian menunjukkan bahwa dua variabel bebas yaitu indeks massa tubuh (IMT) ibu prahamil dan kenaikan berat badan selama kehamilan mempunyai hubungan yang bermakna terhadap berat badan lahir bayi. Signifikasi IMT ( $p=0,040<0,05)$. Signifikasi kenaikan berat badan selama kehamilan $(p=$ $0,000<0,05$ ). Simpulan penelitian didapatkan bahwa indeks massa tubuh ibu prahamil dan kenaikan berat badan selama kehamilan mempengaruhi berat badan lahir bayi di RSUD Dr. M. Soewandhie Surabaya.
\end{abstract}

\begin{abstract}
Mother nutrition status before and during pregnancy is one of factor that affect neonatal birth weight. The underweight or overweight of mother pre-pregnancy weight and weight gain during pregnancy will make a risky pregnancy. The objective of this study is to learn the correlation between pre-pregnancy body mass index (BMI) and gestational weight gain with neonatal birth weight. This study used observational analytic with cross sectional phenomenological. The sample of this study is all of postpartum mother at postpartum room in RSUD dr. M. Soewandhie Surabaya. The number of sample are 79 postpartum mothers. The data analysis of this study is Spearman correlation coefficient (rs). The result showed that two free variables (pre-pregnancy BMI and gestational weight gain) have significant correlation to neonatal birth weight. The significanty of the $B M I(P=0,040<0,05)$. Weight gain significanty during pregnancy $(P=0,000<0,05)$. The conclusion showed that pre-pregnancy body mass index (BMI) and gestational weight gain affected neonatal birth weight.
\end{abstract}

\section{A. LATAR BELAKANG}

Kehamilan merupakan masa kehidupan yang penting, di masa ini ibu harus mempersiapkan diri sebaikbaiknya untuk menyambut kelahiran bayinya. Ibu yang sehat akan melahirkan bayi yang sehat. Salah satu faktor yang mempengaruhi kesehatan ibu adalah keadaan gizi ibu (Waryana, 2010). Status gizi ibu yang buruk, baik sebelum kehamilan dan selama kehamilan akan menyebabkan berat badan kurang dari normal (low birth weight) yang dikenal dengan istilah berat badan lahir rendah (BBLR), terhambatnya pertumbuhan otak janin, anemia pada bayi baru lahir, bayi baru lahir mudah terinfeksi, abortus dan sebagainya (Supariasa, 2012). Wanita dengan status gizi rendah atau biasa dikatakan BMI rendah, memiliki efek negatif pada hasil kehamilan, biasanya berat badan lahir bayi rendah atau kelahiran preterm, sedangkan wanita dengan status gizi berlebihan atau IMT obesitas dikatakan memiliki risiko tinggi terhadap kehamilan seperti keguguran, persalinan operatif, preeklamsia, thromboemboli, kematian perinatal dan makrosomia (Sativa, 2011).

Menilai berat badan sebelum kehamilan sangat penting dari segi kesehatan bagi ibu dan bayi. Jika Ibu hamil dengan berat badan yang berlebihan sebelum kehamilan, maka pertambahan yang dianjurkan harus lebih kecil daripada ibu dengan berat badan ideal karena bila ibu hamil itu mempunyai peningkatan berat badan yang terlalu berlebihan akan berisiko terjadinya komplikasi kehamilan seperti diabetes gestasional (kenaikan kadar gula darah karena adanya proses kehamilan) atau terjadinya preeklampsia (keracunan kehamilan karena terjadi peningkatan tekanan darah) (Suririnah, 2008). 
Kehamilan menyebabkan meningkatnya metabolisme energi, oleh karena itu kebutuhan energi dan zat gizi lainnya meningkat selama kehamilan. Peningkatan energi dan zat gizi tersebut diperlukan untuk pertumbuhan dan perkembangan janin, pertambahan besarnya organ kandungan, perubahan komposisi, dan metabolisme tubuh ibu. Kekurangan zat gizi tertentu yang diperlukan ibu saat hamil dapat menyebabkan janin tumbuh tidak sempurna. Ibu hamil memerlukan semua tambahan zat gizi, namun yang seringkali menjadi kekurangan adalah energi protein dan beberapa mineral seperti zat besi dan kalsium (Nasution, 1998 dalam Waryana 2010).

Prevalensi BBLR lebih tinggi di Asia dari pada di tempat lain, hal ini terutama dipengaruhi oleh gizi buruk ibu sebelum dan selama kehamilan (Muthayya, 2009). Hasil Riskesdas 2007, penyebab kematian bayi baru lahir o - 6 hari di Indonesia adalah gangguan pernapasan $(36,9 \%)$, prematuritas $(32,45)$, sepsis $(12 \%)$, hipotermi $(6,8 \%)$, kelainan darah $(6,6 \%)$, dan lain-lain. Penyebab kematian bayi $7-28$ hari adalah sepsis $(20,5 \%)$, kelainan congenital (18,1\%), pneumonia (15,4\%), prematuritas dan BBLR (30,2\%). Hasil Riskesdas tahun 2010 persentase anak balita yang mempunyai berat badan lahir $<2.500$ gram sebesar $11,1 \%$, $2.500-3.999$ gram sebesar $82,5 \%$, dan $>4.000$ gram sebesar $6,4 \%$. Persentase berat badan lahir $<2.500$ gram anak perempuan $(12,4 \%)$ lebih tinggi dari pada anak laki-laki (9,8\%). Persentase berat badan bayi baru lahir anak balita menurut provinsi, di Jawa Timur sebesar 10,1\% berat badan lahir < 2.500 gram, 84,5\% dengan berat badan lahir $2.500-3.999$ gram, dan $5,4 \%$ dengan berat badan lahir $>4.000$ gram .

Kematian neonatal tahun 2010 di Jawa Timur sebanyak 4.634, BBLR menjadi penyebab tertinggi yaitu sebanyak 1.821. Jumlah kematian bayi tahun 2011 di Jawa Timur sebanyak 6.095. Penyebab teratas kematian bayi tersebut adalah BBLR sebanyak 1.874 kemudian diikuti oleh asfiksia sebanyak 1.309 dan kelainan kongenital sebanyak 854 (Dinas Kesehatan Provinsi Jawa Timur, 2011). Kasus BBLR di Surabaya mengalami penurunan dari tahun 2010 sebesar 1.596 (3,91\%) menjadi 889 (2,47\%) pada tahun 2011 (Dinas Kesehatan Kota Surabaya, 2010-2011).

Tujuan dari Penelitian ini adalah:

1. Mempelajari indeks massa tubuh ibu prahamil yang bersalin di RSUD Dr. M. Soewandhie Surabaya.

2. Mempelajari kenaikan berat badan selama kehamilan pada ibu bersalin di RSUD Dr. M. Soewandhie Surabaya.

3. Mempelajari gambaran berat badan lahir bayi yang dilahirkan di VK RSUD Dr. M. Soewandhie Surabaya.

Manfaat dari penelitian ini diharapkan dapat digunakan sebagai bahan masukan bagi tenaga kesehatan dalam peningkatan mutu pelayanan kesehatan mengenai pentingnya memperhatikan status gizi ibu sebelum dan selama kehamilan, sehingga insiden BBLR dapat ditekan.

Keterbatasan dalam penelitian ini adalah:

1. Penelitian ini hanya terbatas pada perhitungan indeks masa tubuh ibu sebelum kehamilan

2. Penelitian ini dilaksanakan RSUD Dr. M. Soewandhie Surabaya dengan pertimbangan jumlah kelahiran di tempat tersebut tinggi

\section{B. METODE PENELITIAN}

Penelitian ini menggunakan rancangan penelitian analitik observasional dengan pendekatan cross sectional Populasi adalah wilayah generalisasi yang terdiri atas: obyek/ subyek yang mempunyai kualitas dan karakteristik tertentu yang ditetapkan oleh peneliti untuk dipelajari dan kemudian ditarik kesimpulannya. Populasi bukan hanya orang tetapi obyek dan bendabenda alam yang lain. Populasi juga bukan sekedar jumlah yang ada pada obyek/subyek yang dipelajari, tetapi meliputi seluruh karakteristik/ sifat yang dimiliki oleh subyek atau obyek itu (Sugiyono, 2011). Populasi dalam penelitian ini adalah seluruh ibu postpartum di ruang nifas RSUD Dr. M. Soewandhie Surabaya periode Mei - Juni 2018 selama tiga minggu yang memenuhi kriteria penelitian.

Sampel dalam penelitian ini adalah seluruh ibu postpartum di ruang nifas RSUD Dr. M. Soewandhie Surabaya periode Mei - Juni 2018 selama tiga minggu yang memenuhi kriteria penelitian. Kriteria inklusi dalam penelitian ini adalah bersedia menjadi reponden, mempunyai buku KIA, dan kehamilan normal. Kriteria eksklusi dalam penelitian ini adalah tidak bersedia menjadi responden, bayi yang dilahirkan adalah bayi kembar, bayi yang memiliki cacat fisik.

Teknik pengambilan sampel dalam penelitian ini adalah Consecutive Sampling yang merupakan bagian dari Nonprobability Sampling Penelitian ini akan dilaksanakan di RSUD Dr. M. Soewandhie Surabaya periode Mei - Juni 2018 selama tiga minggu, berdasarkan pertimbangan jumlah ibu postpartum di ruang nifas RSUD Dr. M. Soewandhie cukup tinggi sehingga memudahkan peneliti dalam pengambilan sampel.

Variabel dalam penelitian ini, yaitu :

a. Variabel terikat/ dependent variable : berat badan lahir bayi

b. Variabel bebas/ independet variable : indeks massa tubuh (IMT) ibu prahamil dan kenaikan berat badan selama kehamilan

Penelitian ini merupakan penelitian korelasi atau membuktikan ada tidaknya hubungan antarvariabel penelitian yang berupa data ordinal dan rasio, sehingga analisa data yang digunakan adalah koefisian korelasi Spearman (rs). 
Prosedur perhitungan koefisien korelasi Spearman dilakukan melalui beberapa tahap yaitu penyusunan peringkat data, penentuan perbedaan peringkat dari pasangan data, dan perhitungan koefisien korelasi, dengan rumus sebagai berikut:

$$
r s=1-\frac{6 \Sigma D 2}{n(n 2-1)}
$$

Keterangan :

rs $\quad=$ koefisien korelasi Spearman

$\mathrm{D}=$ selisih ranking tiap pengamatan/ perbedaan peringkat

$\mathrm{n}=$ banyaknya pengamatan/ pasangan data

TABEL 1

Interpretasi nilai $\mathbf{r}$

\begin{tabular}{ll}
\hline Besarnya nilai $\mathrm{r}$ & Interpretasi \\
\hline & \\
Antara 0,800 - 1,00 & Tinggi \\
Antara 0,600 - 0,800 & Cukup \\
Antara 0,400 - 0,600 & Agak rendah \\
Antara 0,200 - 0,400 & Rendah \\
Antara 0,000 - 0,200 & Sangat rendah (tak \\
& ।berkorelasi) \\
\hline
\end{tabular}

\section{HASIL DAN PEMBAHASAN}

\section{HASIL PENELITIAN}

RSUD dr. M. Soewandhie adalah rumah sakit kelas tipe C milik Pemerintah Kota Surabaya yang terletak di jalan Tambakrejo 45-47 Surabaya dan merupakan rumah sakit rujukan.

Jenis pelayanan yang terdapat di rumah sakit ini adalah 1) pelayanan medis/ pelayanan kesehatan antara lain pelayanan rawat inap meliputi: rawat inap anak, rawat inap bersalin, rawat inap bedah, rawat inap penyakit dalam, rawat inap jantung, rawat inap paru dan pelayanan rawat jalan meliputi: poliklinik penyakit dalam, poliklinik anak, poliklinik kandungan dan kebidanan, poliklinik bedah umum, poliklinik jantung, poliklinik penyakit mata, poliklinik THT, poliklinik penyakit kulit dan kelamin, poliklinik gigi, poliklinik paru, poliklinik orthopedi, pelayanan klinik VCT. 2) Pelayanan penunjang meliputi pelayanan radiology, pelayanan laboratorium, farmasi/ apotek, konsultasi gizi, ambulance. 3). Pelayanan rawat darurat yang dibuka selama 24 jam setiap hari.

\section{a. Karakteristik Responden Berdasarkan Usia \\ TABEL 2}

Distribusi frekuensi responden berdasarkan usia saat hamil

\begin{tabular}{lccc}
\hline No & $\begin{array}{c}\text { Usia responden } \\
\text { (tahun) }\end{array}$ & Frekuensi & $\begin{array}{c}\text { Persentase } \\
(\%)\end{array}$ \\
\hline 1. & $<20$ & 2 & 2,5 \\
\hline 2. & $20-35$ & 64 & 81 \\
\hline 3. & $>35$ & 13 & 16,5 \\
\hline & Total & 79 & 100 \\
\hline
\end{tabular}

(Sumber: Data sekunder 2018)
Tabel 2 menunjukkan bahwa sebagian besar responden berusia $20-35$ tahun. Dalam penelitian ini tidak ditentukan kriteria khusus untuk usia responden. Karakteristik responden berdasarkan kepatuhan pemeriksaan kehamilan

TABEL 3

Distribusi frekuensi responden berdasarkan kepatuhan ANC

\begin{tabular}{llcc}
\hline No. & Ante natal care & Frekuensi & Persentase (\%) \\
\hline 1. & Teratur & 70 & 88,6 \\
\hline 2. & Tidak teratur & 9 & 11,4 \\
\hline & Total & 79 & 100 \\
\hline
\end{tabular}

(Sumber: Data sekunder 2018)

Tabel 3 menunjukkan bahwa sebagian besar responden $70 \quad(88,6 \%)$ melakukan pemeriksaan kehamilan secara teratur.

\section{b. Karakteristik Responden Berdasarkan Paritas} TABEL 4

Distribusi frekuensi responden berdasarkan paritas/jumlah anak

\begin{tabular}{lccc}
\hline No. & Paritas & Frekuensi & Persentase (\%) \\
\hline 1. & PI & 34 & 43 \\
\hline 2. & PII & 19 & 24,1 \\
\hline 3. & PIII & 16 & 20,3 \\
\hline 4. & PIV & 9 & 11,4 \\
\hline 5. & PV & 1 & 1,3 \\
\hline & Total & 79 & 100 \\
\hline
\end{tabular}

(Sumber: Data sekunder 2018)

Tabel 4 menunjukkan bahwa responden terbanyak mempunyai 1 anak, yaitu sebanyak 34 (43\%) responden. Karakteristik responden berdasarkan berat badan lahir bayi

TABEL 5

Distribusi frekuensi responden berdasarkan berat badan lahir bayi

\begin{tabular}{lccc}
\hline No. & $\begin{array}{c}\text { Berat badan } \\
\text { lahir bayi (gram) }\end{array}$ & Frekuensi & $\begin{array}{c}\text { Persentase } \\
(\%)\end{array}$ \\
\hline 1. & $<2500$ & 4 & 5,1 \\
\hline 2. & $2500-4000$ & 70 & 88,6 \\
\hline 3. & $>4000$ & 5 & 6,3 \\
\hline & Total & 79 & 100 \\
\hline
\end{tabular}

(Sumber: Data sekunder 2018)

Tabel 5 menunjukkan bahwa sebagian besar, yaitu sebanyak $70(88,6 \%)$ responden melahirkan bayi dengan berat badan $2500-4000$ gr.

c. Penyajian Karakteristik Data Khusus

1). Indeks massa tubuh ibu prahamil

TABEL 6

Distribusi frekuensi responden berdasarkan indeks massa tubuh ibu prahamil

\begin{tabular}{cccc}
\hline No. & IMT Prahamil & Frekuensi & $\begin{array}{c}\text { Persentase } \\
(\%)\end{array}$ \\
\hline 1. & Kurang & 16 & 20,3 \\
\hline 2. & Normal & 37 & 46,8 \\
\hline 3. & Berlebih & 18 & 22,8 \\
\hline 4. & Obesitas & 8 & 10,1 \\
\hline
\end{tabular}




$$
\text { Total }
$$$$
79
$$

100

(Sumber: Data sekunder 2018)

Tabel 6 menunjukkan bahwa indeks massa tubuh ibu prahamil yang diambil sebagai sampel dalam penelitian ini paling banyak terdapat pada kelompok rentang normal yaitu sebanyak 37 (46,8\%) responden.

2). Kenaikan berat badan ibu selama kehamilan

\section{TABEL 7}

Distribusi frekuensi responden berdasarkan kenaikan berat badan selama kehamilan

\begin{tabular}{|c|c|c|c|}
\hline No. & $\begin{array}{c}\text { Kenaikan berat badan } \\
\text { selama kehamilan }\end{array}$ & Frekuensi & $\begin{array}{c}\text { Persentase } \\
(\%)\end{array}$ \\
\hline 1. & Kurang & 26 & 32,9 \\
\hline 2. & Normal & 33 & 41,8 \\
\hline 3. & Berlebih & 20 & 25,3 \\
\hline & Total & 79 & 100 \\
\hline
\end{tabular}

(Sumber: Data sekunder 2018)

Tabel 5.6 menunjukkan bahwa sebagian besar 33 (41,8\%) responden mengalami kenaikan berat badan normal.

\section{PEMBAHASAN}

a. Hubungan antara Indeks Massa Tubuh Ibu Prahamil dengan Berat Badan Lahir Bayi

\section{TABEL 8}

Hubungan indeks massa tubuh ibu prahamil dengan berat badan lahir bayi

\begin{tabular}{|c|c|c|c|c|c|c|c|c|}
\hline \multirow{3}{*}{$\begin{array}{c}\text { IMT } \\
\text { Prahamil }\end{array}$} & \multicolumn{6}{|c|}{ Berat badan lahir bayi } & & \multirow[b]{2}{*}{ Total } \\
\hline & \multicolumn{2}{|c|}{$<2500$} & \multicolumn{2}{|c|}{$\begin{array}{c}2500- \\
4000\end{array}$} & \multicolumn{2}{|c|}{$>4000$} & & \\
\hline & $\mathrm{N}$ & $\%$ & $\mathrm{~N}$ & $\%$ & $\mathrm{~N}$ & $\%$ & $\mathrm{~N}$ & $\%$ \\
\hline Kurang & 1 & 6,3 & 15 & 93,8 & $\mathbf{O}$ & $\mathrm{O}$ & 16 & 100 \\
\hline Normal & 2 & 5,4 & 34 & 91,9 & 1 & 2,7 & 37 & 100 \\
\hline Berlebih & 1 & 5,6 & 15 & 83,3 & 2 & 11,1 & 18 & 100 \\
\hline Obesitas & $\mathrm{O}$ & $\mathrm{O}$ & 6 & 75,0 & 2 & 25,0 & 8 & 100 \\
\hline
\end{tabular}

Tabel 8 merupakan hasil crosstabulation antara indeks massa tubuh prahamil dengan berat badan lahir bayi. Dengan uji statistik Spearman's didapatkan nilai signifikasi 0,040 yang berarti signifikasi <0,05, maka Ho ditolak menunjukkan bahwa ada hubungan yang bermakna antara indeks massa tubuh prahamil dengan berat badan lahir bayi. Nilai koefisian korelasi (r) sebesar 0,232 menunjukkan bahwa hubungan yang terjadi antara kedua variabel adalah rendah.

Hasil analisa uji Spearman didapatkan nilai yang bermakna secara statistik yang dapat dilihat pada tabel 5.7, ini menunjukkan bahwa ada hubungan yang bermakna antara indeks massa tubuh prahamil dengan berat badan lahir bayi.

WHO menyebutkan IMT (indeks massa tubuh) atau BMI (Body Mass Index) adalah petunjuk sederhana dari berat dan tinggi badan yang biasanya digunakan untuk mengklarifikasikan status berat badan kurang, berat badan berlebih, dan obesitas pada orang dewasa, yaitu dengan membagi berat badan dalam kilogram dengan tinggi badan dalam meter persegi. Berat badan lahir merupakan hasil interaksi dari berbagai faktor melalui suatu proses yang berlangsung selama berada dalam kandungan. Faktor-faktor yang dapat mempengaruhi berat badan lahir bayi salah satunya adalah status gizi ibu. Berat badan ibu sebelum hamil kurang (underweight) atau lebih (overweight) dari normal akan membuat kehamilan menjadi berisiko (Waryana, 2010). Wanita dengan status gizi rendah atau biasa dikatakan BMI rendah, memiliki efek negatif pada hasil kehamilan, biasanya berat badan lahir bayi rendah atau kelahiran preterm, sedangkan wanita dengan status gizi berlebihan atau IMT obesitas dikatakan memiliki risiko tinggi terhadap kehamilan seperti keguguran, persalinan operatif, preeklamsia, thromboemboli, kematian perinatal dan makrosomia (Sativa, 2011).

Hasil penelitian ini sesuai dengan hasil penelitian Mei-Yueh Chang (2010) yang menggunakan 263 responden untuk mengetahui pengaruh indeks massa tubuh sebelum hamil terhadap berat badan lahir bayi, rata-rata IMT yang didapat dari penelitian tersebut 21,19 $\mathrm{kg} / \mathrm{m} 2$ (standar deviasi 16,22 - 32,05). Rata-rata berat badan bayi yang lahir 3192,57 gram (standar deviasi 2120 - 4390). Ibu dengan IMT sebelum hamil 24-27 melahirkan bayi dengan berat badan lebih tinggi daripada ibu yang memiliki IMT $>27$ dan < 18,5 (nilai p dari penelitian ini sebesar o.001), yang menunjukkan adanya hubungan yang bermakna antara IMT sebelum hamil dan berat badan lahir bayi.

Hasil penelitian ini menunjukkan nilai koefisien korelasi (r) sebesar o,232 menunjukkan hubungan yang terjadi antara kedua variabel adalah rendah. Hal ini terjadi dapat dikarenakan sebagian besar sampel berasal dari kelompok bayi dengan berat badan lahir normal, sedangkan kelompok sampel dengan berat badan lahir rendah dan makrosomia tidak banyak.

\section{b. Hubungan antara Kenaikan Berat Badan Selama Kehamilan dengan Berat Badan Lahir} Bayi

TABEL 9

Hubungan antara kenaikan berat badan selama kehamilan dengan berat badan lahir bayi

\begin{tabular}{|c|c|c|c|c|c|c|c|c|}
\hline \multirow{3}{*}{$\begin{array}{c}\text { Kenaikar } \\
\text { BB }\end{array}$} & \multicolumn{6}{|c|}{ Berat badan lahir bayi } & \multirow{2}{*}{\multicolumn{2}{|c|}{ Total }} \\
\hline & \multicolumn{2}{|c|}{$<2500$} & \multicolumn{2}{|c|}{$\begin{array}{c}2500- \\
4000\end{array}$} & \multicolumn{2}{|c|}{$>4000$} & & \\
\hline & $\mathrm{N}$ & $\%$ & $\mathrm{~N}$ & $\%$ & $\mathrm{~N}$ & $\%$ & $\mathrm{~N}$ & $\%$ \\
\hline Kurang & 2 & 7,7 & 24 & 92,3 & O & 0 & 26 & 100 \\
\hline Normal & 2 & 6,1 & 29 & 87,9 & 2 & 6,1 & 33 & 100 \\
\hline Berlebih & 0 & 0 & 17 & 85,0 & 3 & 15,0 & 20 & 100 \\
\hline
\end{tabular}

Tabel 9 merupakan hasil crosstabulation antara kenaikan berat badan selama kehamilan dengan berat badan lahir bayi. Dengan uji statistik Spearman's didapatkan nilai signifikasi o,ooo yang berarti signifikasi <0,05, maka Ho ditolak menunjukkan bahwa ada hubungan yang bermakna antara kenaikan berat badan selama hamil dengan berat badan lahir bayi. Nilai koefisian korelasi (r) sebesar 0,424 menunjukkan bahwa 
hubungan yang terjadi antara kedua variabel adalah agak rendah.

Hasil analisa uji Spearman didapatkan nilai yang bermakna secara statistik yang dapat dilihat pada tabel 5.8, ini menunjukkan bahwa ada hubungan yang bermakna antara kenaikan berat badan selama hamil dengan berat badan lahir bayi.

Kenaikan berat badan selama hamil kurang (underweight) atau lebih (overweight) dari normal akan membuat kehamilan menjadi berisiko. Kekurangan gizi pada ibu hamil dapat mempengaruhi proses pertumbuhan janin dan dapat menimbulkan keguguran, abortus, bayi lahir mati, kematian neonatal, cacat bawaan, anemia pada bayi, asfiksia intra partum, dan berat badan lahir rendah (Waryana, 2010).

Peningkatan berat badan yang tepat bagi setiap ibu hamil saat ini didasarkan pada indeks massa tubuh prakehamilan (body mass index/ BMI), atau dikenal dengan istilah IMT (indeks massa tubuh) yang menggambarkan perbandingan antar berat badan dengan tinggi badan ibu (Fraser, 2009).

Berat badan ibu sebelum hamil dan penambahan berat badan selama hamil merupakan penentu utama berat bayi saat lahir. Wanita dengan berat badan rendah (misalnya $<55 \mathrm{~kg}$ ) sebelum hamil yang mencapai sedikit kenaikan berat badan ( $<4.500$ gram) selama hamil mempunyai insiden lebih tinggi untuk melahirkan bayi dengan berat badan lahir rendah dibandingkan ibu-ibu dengan berat badan lebih besar yang mencapai lebih banyak kenaikan berat badan selama hamil (Benson, 2008). Peningkatan berat badan selama kehamilan mencakup produk konsepsi (janin, plasenta, dan cairan amniotik), dan hipertrofi beberapa jaringan ibu hamil (uterus, payudara, darah, cadangan lemak, cairan ekstraseluler dan ekstravaskuler). Sebagian besar protein terdapat pada janin, tetapi terdapat juga pada uterus, darah, plasenta, dan payudara. Sebagian besar deposit lemak terdapat pada jaringan adiposa maternal, terutama regio gluteal dan paha atas, dan juga janin yang merupakan satu-satunya hal penting utama lainnya (Prentice et al, 1996 dalam Fraser, 2009).

Hasil penelitian ini sesuai dengan hasil penelitian Mardiah (2011) yang menunjukkan bahwa berdasarkan nilai rata-rata kenaikan berat badan responden selama kehamilan yaitu 12,3 kg dengan standar deviasi yaitu 1,6 dan kenaikan berat badan terendah $10 \mathrm{~kg}$, sedangkan berat badan tertinggi $16 \mathrm{~kg}$. Dari hasil uji statistik dengan Korelasi Product Moment diperoleh nilai p value $=0,000$ berarti bahwa adanya hubungan yang signifikan antara peningkatan berat badan selama kehamilan terhadap berat badan bayi baru lahir, dan diperoleh nilai $(\mathrm{r}=0,506)$ ini berarti adanya hubungan yang cukup kuat dengan arah korelasi positif artinya semakin meningkat berat badan ibu selama kehamilan maka semakin meningkat pula berat badan bayinya.

Hasil penelitian ini juga sesuai dengan hasil penelitian Hayati (2011) menyebutkan bahwa dari sampel yang berjumlah 101 orang, mayoritas ibu hamil (71 orang) memiliki pertambahan berat badan saat kehamilan $>20 \%$ dari berat badan sebelum hamil. Bayi yang dilahirkan mayoritas memiliki berat lahir $>2.500$ gr. Hasil penelitian ini didapati bahwa ada hubungan antara pertambahan berat badan ibu saat hamil dengan berat bayi lahir dimana $\mathrm{p}=0,003(<0,05)$.

Hasil penelitian dan teori yang dikemukakan menunjukkan bahwa ada hubungan antara kenaikan berat badan selama kehamilan dengan berat badan lahir bayi dengan nilai koefisien korelasi sebesar (r) sebesar 0,424, maka hubungan yang terjadi antara kedua variabel adalah agak rendah.

\section{SIMPULAN DAN SARAN}

\section{KESIMPULAN}

Hasil penelitian mengenai hubungan antara indeks massa tubuh ibu prahamil dan kenaikan berat badan selama kehamilan dengan berat badan lahir bayi di RSUD Dr. M. Soewandhie Surabaya dapat disimpulkan bahwa:

1. Indeks massa tubuh ibu sebelum hamil mempengaruhi berat badan lahir bayi di RSUD Dr. M. Soewandhie Surabaya.

2. Kenaikan berat badan ibu selama hamil mempengaruhi berat badan lahir bayi di RSUD Dr. M. Soewandhie Surabaya.

3. Berat badan bayi yang dilahirkan di RSUD Dr. M. Soewandhie Surabaya bervariasi, yaitu <2500, 2500 -4000 , dan $>4000$ gram.

\section{SARAN}

1. Bagi tempat penelitian

Memberikan penyuluhan kepada ibu yang memiliki berat badan lahir rendah untuk memperbaiki status gizinya sebelum memutuskan untuk hamil lagi.

2. Bagi institusi pendidikan

Institusi pendidikan diharapkan dapat lebih meningkatkan proses pembelajaran terutama di bidang penelitian dan karya tulis ilmiah.

3. Bagi petugas kesehatan (Bidan)

Mengkaji berat badan ibu sebelum hamil pada saat kunjungan pertama masa kehamilan. Mencatat kenaikan berat badan ibu setiap kali pemeriksaan untuk mengeevaluasi normal atau tidaknya kenaikan berat badan yang dialami ibu selama kehamilan. Selain itu Bidan juga diharapkan dapat memberikan penyuluhan kepada calon dan ibu hamil untuk memperhatikan gizi sebelum dan selama kehamilan.

4. Bagi Peneliti Lain

Hasil Penelitian ini dapat digunakan sebagai landasan teoritis yang berdasarkan dari hasil riset tentang persiapan gizi sebelum kehamilan, saat kehamilan dan berat badan lahir bayi. 


\section{DAFTAR RUJUKAN}

[1] Chang, Mei-Yueh, Kuo, Chun-Hua, and Chiang, Kuei-Feng, 2010. "The Effects of Pre-pregnancy Body Mass Index and Gestational Weight Gain on Neonatal Birth Weight in Taiwan". International Journal of Nursing and Midwifery, Vol. 2(2), pp 28

[2] Dinas Kesehatan Kota Surabaya, 2010-2011

[3] Dinas Kesehatan Provinsi Jawa Timur, 2010-2011

[4] Fraser, Diane M. and Cooper, Margaret A., 2009. Myles Buku Ajar Bidan. Jakarta: EGC

[5] Hayati, Nur Akmal. 2011. Hubungan Pertambahan Berat Badan Ibu Saat Hamil dengan Berat Bayi Lahir di Praktik Bidan Sumiarini, Amd.Keb Kecamatan Medan Johor. Diakses: 04 Juli 2012. Diunduh dari http://repository.usu.ac.id/handle/123456789/215 32

[6] Leveno, Kenneth J. et al., 2009. Obstetri Williams: Panduan Ringkas. Jakarta: EGC

[7] Mardiah. 2011. Pengaruh Peningkatan Berat Badan Selama Kehamilan terhadap Berat Badan Bayi Baru Lahir di Klinik Nurhasanah tahun 2010-2011. Diakses : 01 Juli 2012. Diunduh dari http://repository.usu.ac.id/handle/123456789/273 18

[8] Sativa, Gadis. 2011. Pengaruh Indeks Massa Tubuh pada Wanita Saat Persalinan terhadap Keluaraan Maternal dan Perinatal di RSUP DR. Kariadi Perode Tahun 2011. Diakses: 12 April 2012. Diunduh dari http://eprints.undip.ac.id/33295/1/Gadis_Sativa.p df

[9] Sugiyono. 2011. Metodologi Penelitian Pendidikan. Bandung: Alfabeta

[10]Supariasa, I Dewa Nyoman. 2012. Penilaian Status Gizi. Jakarta: EGC

[11] Suririnah. 2008. Buku Pintar Kehamilan dan Persalinan. Jakarta: Gramedia Pustaka Utama

[12]Waryana. 2010. Gizi Reproduksi. Yogyakarta: Pustaka Rihama

\section{PROFIL PENULIS UTAMA}



\section{Data Pribadi}

Nama

Alamat

Telepon

e-mail

: Irma Maya Puspita, S.Keb., Bd., M.Kes

Tempat Tanggal Lahir: Banyuwangi, o7 Agustus 1989 o01 Desa Glagahagung,

Kec. Purwoharjo,

Kab. Banyuwangi, Jawa Timur

: 085336862676

: irmamayapuspita@gmail.com
: Dusun Jatiluhur RT 003/ RW
Jenis Kelamin

Status

Pekerjaan

: Perempuan

: Menikah

: Dosen S1 Pendidikan Profesi

Bidan Fakultas Ilmu Kesehatan

Univ. Muhammadiyah Surabaya

\section{Pendidikan}

\begin{tabular}{|l|l|c|}
\hline No. & \multicolumn{1}{|c|}{ Nama Sekolah } & Periode \\
\hline 1. & $\begin{array}{l}\text { SD Muhammadiyah 012 } \\
\text { Glagahagung }\end{array}$ & $1996-2002$ \\
\hline 2. & SLTP Negeri 1 Purwoharjo & $2002-2005$ \\
\hline 3. & SMA Negeri 1 Genteng & $2005-2008$ \\
\hline 4. & $\begin{array}{l}\text { Program Studi S1 Pendidikan } \\
\text { Bidan Universitas Airlangga }\end{array}$ & $2008-2012$ \\
\hline 5. & Profesi Bidan & $2012-2013$ \\
\hline 6. & $\begin{array}{l}\text { Program Studi Ilmu Kesehatan } \\
\text { Reproduksi Jenjang Magister } \\
\text { Universitas Airlangga }\end{array}$ & $2013-2015$ \\
\hline
\end{tabular}

\section{Pengalaman Kerja}

- Asisten Dosen Prof. Dr. Budi Santoso, dr., Sp.OG (K)

- Tim Akreditasi Program Pendidikan Magister Program Studi Ilmu Kesehatan Reproduksi FK Universitas Airlangga

- Staff Pengajar Program Studi Kebidanan Fakultas Ilmu Kesehatan Universitas Muhammadiyah Surabaya 